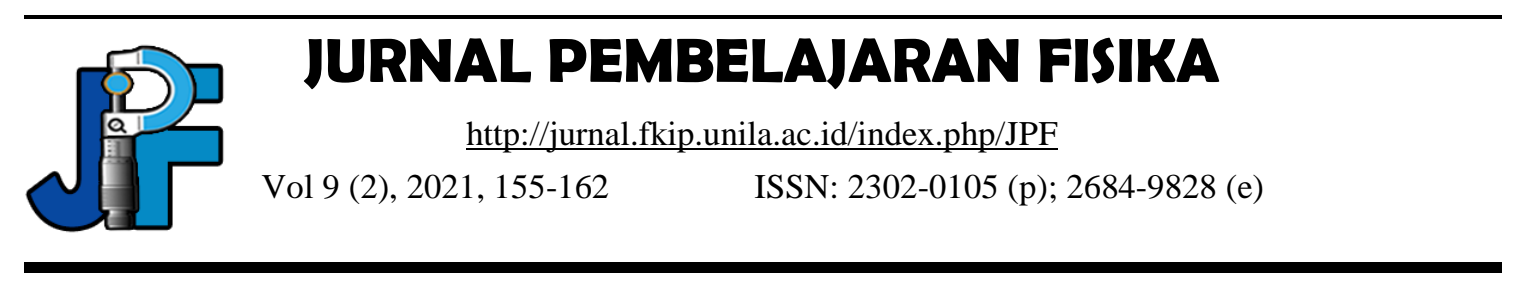

\title{
Diagnosis of Student Misconception in Heat Material Using Tier Test
}

\author{
Heny Ekawati Haryono ${ }^{1 *}$, Khafidhoh Nurul Aini ${ }^{1}$, Achmad Samsudin ${ }^{2}$, Parsaoran \\ Siahaan $^{2}$ \\ ${ }^{1}$ Universitas Islam Darul 'Ulum, Indonesia \\ ${ }^{2}$ Universitas Pendidikan Indonesia, Indonesia \\ *e-mail: henny@unisda.ac.id
}

\begin{abstract}
Students, basically, possess prior knowledge or conception regarding a concept, even before they study it formally in the school. Sometimes, their conceptions are inconsistent with scientific concept and resulting misconceptions. Some studies found that students encounter misconception of some concepts, particularly in Physics. Three-tier Test is an instrument used to identify student's misconception and lack of knowledge. A misconception should be differentiate from a lack of knowledge because remediation of a misconception is more difficult than remediation of a lack of knowledge. Besides, both of them may entail different instructional methods. This study focused on diagnosing students' misconceptions of heat using Three-tier Test. The study is aimed to explain in what concepts the students encounter misconceptions of heat and to explain the prevalence of students' misconceptions of heat. The method used in this study was a descriptive-exploratory research with non-experimental design. The sample of this study was 150 Grade VII students of five different State Junior High School in Lamongan, East Java. The data was collected through written test using Three-tier Test and administered once. The results showed that students encounter misconceptions in 6 concepts of heat comprising energy, heat, temperature, mass, specific heat capacity, vaporizing, boiling, pressure, boiling point, freezing, and freezing point. Moreover, the results showed that $88 \%$ of the students encounter misconception, where the most frequently appeared is misconception about energy and heat that is objects could have a certain quantity of heat in them.
\end{abstract}

Keywords: misconception, heat, three tier test

DOI: http://dx.doi.org/10.23960/jpf.v9.n2.202104 


\section{INTRODUCTION}

Physics is the basic science of the development of other sciences and technology. The role of physics in the development of science is very helpful for human life. Given the important role of physics, this science should be well understood by students. One of the concepts of physics that is closely related to student life and students often experience misconceptions is the concept of temperature and heat. Some researchers found that students think temperature and heat are the same thing (Haryono, 2018)(Paul, 2013). Other researchers noted students' thoughts that the temperature of an object depends on the size / mass where if the object is large the temperature is also large, and vice versa (Wahidah S. et al., 2017), the temperature of an object continues to increase when it changes (Widiyatmoko \& Shimizu, 2018), if the mass is small, the heat will be absorbed is greater so that the temperature increases quickly (Maison et al., 2020), and if the heat capacity is large, the temperature objects will quickly rise (Aulia et al., 2018). Students can study physics through various learning sources, one of which is textbooks.

Physics is a branch of science that discusses natural phenomena with all their physical dynamics. Physics is also a science that learns about the characteristics and basic properties of matter, various forms of energy and the way matter and energy interact. The knowledge gained by students in physics learning is basically concepts. This concept is the basis for thinking and solving problems. Science materials studied in junior high school cover 3 fields of study, one of which is the field of Physics. One of the physics materials learned by junior high school students is calorific. This material is important to learn and understand because it has a close connection to daily life (Matraeva et al., 2020).

The main task of a teacher in learning is not only to convey material, but also to instill it understanding and concept correctly. The teacher must first know the initial concepts (preconceptions) that exist in students are used to be able to design learning that allows students constructing the conception, according to constructivism theory, new material or lessons must be able connected and continued with students' existing conceptions or if preconceptions were too distorted from these preconceptions must be dismantled and rebuilt (Berg, 1991)

Misconception is a concept that is believed by people even though the concept is wrong. In learning physics, some teachers have problems how to properly embed concepts in the student, because in the student's mind there is already deep knowledge and experience himself about physical phenomena which are considered to be exactly the same as the existing concepts in the theoretical study of physics, one of them is the misconception about temperature and heat. Since childhood students have felt hot and cold, if it is near the fire it will be hot and when it touches the ice it will feel cold, so the students will explore the environment around him actively includes the events he experiences in his daily life through the assimilation and accommodation process. Some students think that between temperature and heat is the same, the measuring instrument is used to measure temperature and heat are also considered the same. 
One of the causes of the low quality of natural sciences education to date is the misconceptions and learning conditions that are less concerned with the pre-conception or initial conception that students have. The conception of physics can occur to anyone at any level of education, whether in elementary school, secondary school, student, even teacher or lecturer (Wahidah S. et al., 2017). According to (Paul, 2013) Misconception is an understanding of different concepts between the concepts that students have and the actual concepts. Student misconceptions in IPA materials can be caused by material containing abstract concepts. Abstract concepts are difficult to understand because they require deep thinking to solve problems that cannot be directly observed (Ulfah \& Fitriyani, 2017). One of them in the field of physics is temperature and calorific matter.

\section{METHOD}

This research is a descriptive study using qualitative descriptive methods in explaining the results of the study. The technique of data collection through tests is to use diagnostic instruments in the form of three tier tests and open interviews. Diagnostic results data is expressed in the form of a percentage of the student conception category. This research was conducted in 5 different schools with random sampling. This research was conducted at SMP Negeri 1 Sukodadi, SMP Negeri 2 Sukodadi, SMP negeri 1 Pucuk, SMP Negeri 1 Lamongan, and SMP Negeri 3 Lamongan in the school year 2020/2021 grade VII students. The test consists of 20 questions, which have been validated by 3 validations consisting of two lecturers and one junior high school physics teacher. After the students studied the calorie material, the students were tested with the questions that the researcher had prepared to further identify the misconceptions found in the students.

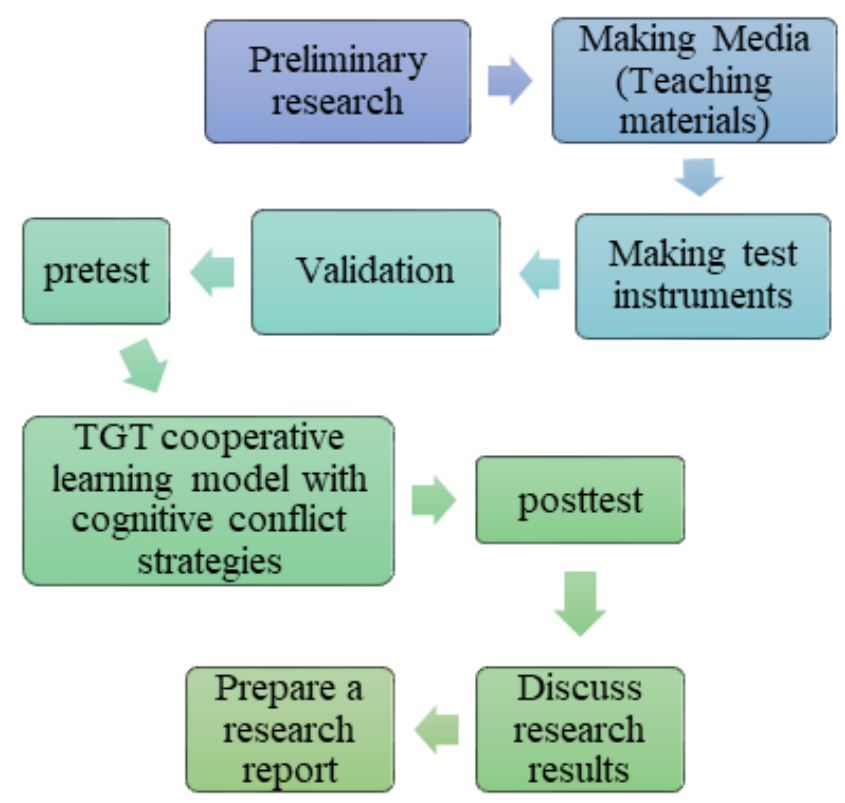

Figure 1. The research procedure 


\section{RESULT AND DISCUSSION}

\section{Research Results}

This research was conducted in SMP Negeri 1 Sukodadi, SMP Negeri 2 Sukodadi, SMP Negeri 1 Pucuk, SMP Negeri 1 Lamongan, and SMP Negeri 3 Lamongan in the school year 2020/2021. This research was conducted on grade VII students. The results of this study show that there are misconceptions on the Heat material. Based on the analysis of data from three tier test diagnostic instruments shows that of all students who include the criteria of mastering the concept there $45 \%$, the Criteria of Misconception exists 35\%, guessing criteria exist $10 \%$ and the criteria do not know the concept exists $10 \%$ can be seen in figure 2 .

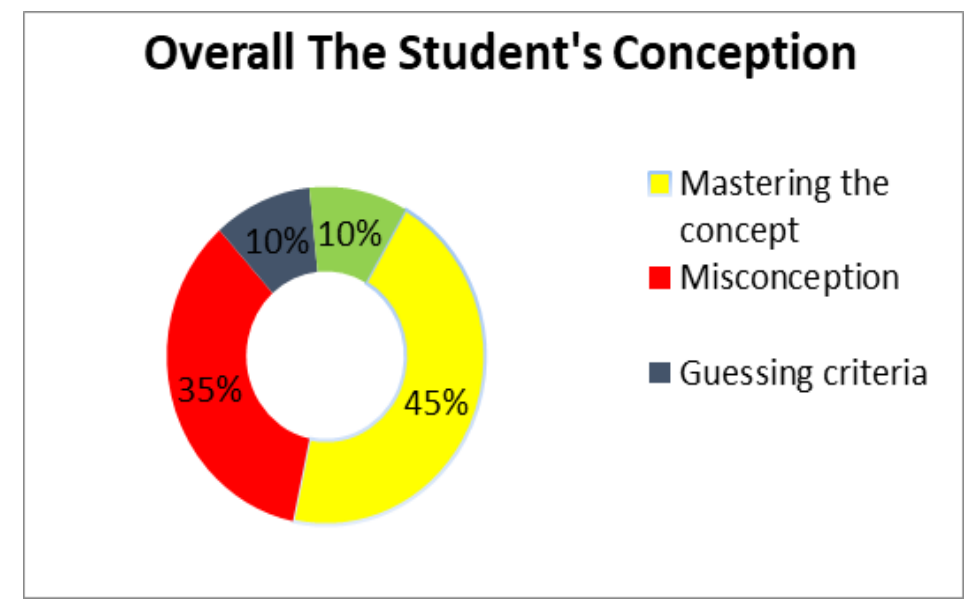

Figure 2. Overall The Student Conception

Based on the results of the student conception analysis, the conception level of grade VII students is still said to be quite low with a $45 \%$ below material. The cause of the inability of student conception is due to the large number of alternative concepts. Based on the results of the identification of the number of students who are classified as misconceptions there $35 \%$, this is the reason it comes from the students themselves. Incoming students do not know the concept is $10 \%$ because they are unable to abstract the concept properly and most students have forgotten or the memory is weak on the previous material they have studied. The weakness of students' memory of the material that has been studied causes students to quickly forget the materials and formulas they have memorized (Haryono, 2020), Only 10\% fall into the guessing category. The causes of misconception can be categorized into five aspects of student-sourced student preconceptions, associative thinking, humanistic thinking, incomplete or incorrect reasons and incorrect student intuition, can be seen in figure 3 . 


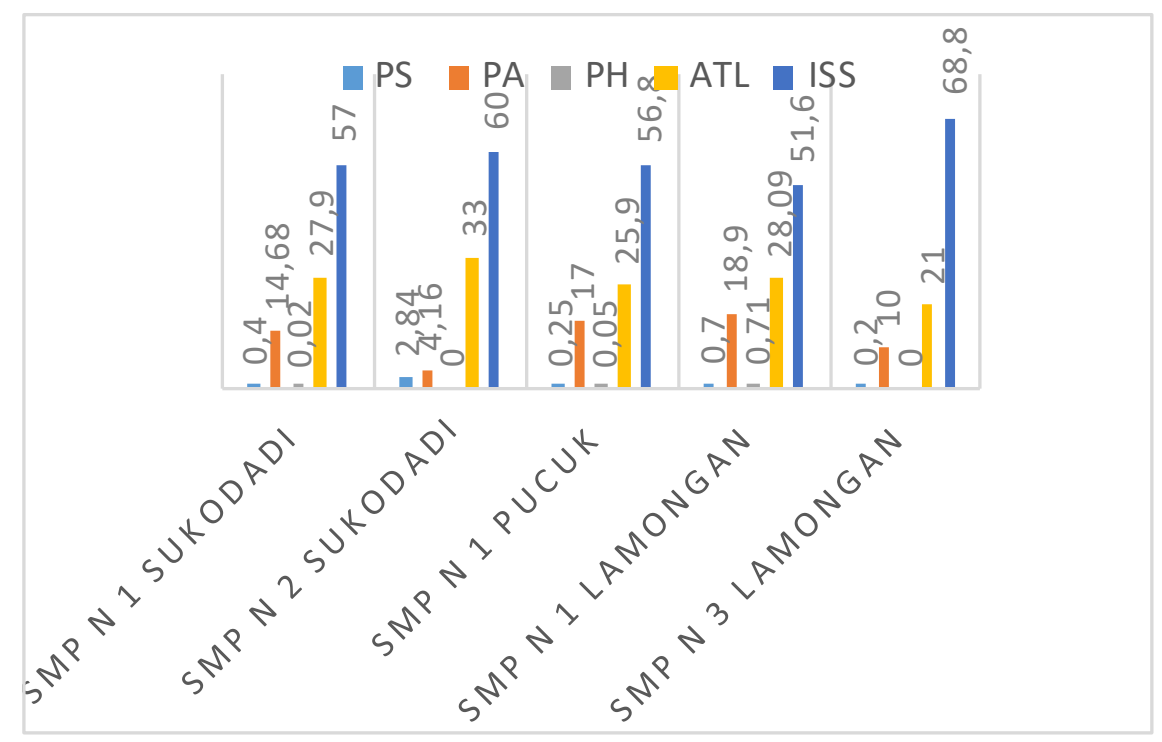

Figure 3. Percentage Of Causes of Misconception

\section{Discussion}

Based on Graph 2, it can be shown that the result of the percentage of the causes of misconceptions from 5 junior high school in Lamongan district. The results showed that the percentage of causes of SMP N 1 Sukodadi Misconceptions in the preconception category of students amounted to $0,4 \%$, Associative Thinking as big as $14,68 \%$, Humanistic thinking is as big as $0,02 \%$, an incomplete or incorrect reason for the $27,9 \%$ and the wrong student intuition amounted to $57 \%$. Persentase causes SMP N 2 Sukodadi misconceptions in the student preconception category of 2,84\%, Associative Thinking as big as $4,16 \%$, Humanistic thinking is as big as $0 \%$, an incomplete or incorrect reason for the $33 \%$ and the wrong student intuition amounted to $60 \%$. The percentage of causes of SMP N 1 Pucuk Misconceptions in the student preconception category is $0,25 \%$, Associative Thinking as big as $17 \%$, Humanistic thinking is as big as $0,05 \%$, an incomplete or incorrect reason for the $25,9 \%$ and the wrong student intuition amounted to 56,8\%. The percentage of causes of SMP $\mathrm{N} 1$ Lamongan misconceptions in the student preconception category is $0,7 \%$, Associative Thinking as big as $18,9 \%$, humanistic thinking is as big as $0,71 \%$, an incomplete or incorrect reason for the $28,09 \%$ and the wrong student intuition amounted to $51,6 \%$. The percentage of causes of SMP N 3 Lamongan misconceptions in the student preconception category is $0,2 \%$, Associative Thinking as big as $10 \%$, Humanistic thinking is as big as $0 \%$, an incomplete or incorrect reason for the $21 \%$ and the wrong student intuition amounted to $66,8 \%$. Of the five aspects of the highest cause of misconception are in the wrong student Intuition category with above average $50 \%$.

The results showed that the highest cause of misconception was in the wrong student intuition category, out of the five junior high school in the district lamongan the wrong student intuition category above average 50\%. The highest occurred in SMP Negeri 3 Lamongan which is as big as $68,8 \%$ and the lowest wrong student intuition is in Junior High School 1 Lamongan State. The next cause of misconception is the 
category of reasons that are incomplete or wrong percentage above average $20 \%$ from five junior high school in Lamongan district. While the percentage of causes of misconceptions in the student preconception category, associative thinking and humanistic thinking are on average below $20 \%$.

From the interview results some students obtained data that almost all students are challenged in working on diagnostic tests in the form of three tier test students are also responsible for providing the answer. Out of the five conception criteria, students are more mastered of concepts than other criteria, because students have obtained calorific material before. However, in the criteria of misconception is also quite a high percentage. This is because there are five aspects of the cause of student misconceptions. The most high aspect of them is the wrong student intuition. According to students, there is a diagnostic test in the form of three tier test capable of providing experience on the concept. However, for a long description of the question and reason it takes a long time to answer.

The heat material essay test was tested on 150 seventh grade students who had studied heat material. Students' conceptions are based on the essential concepts tested on the essay test, namely definition of heat. The number of questions that discuss the meaning of heat is no. 1 and 2. The number of students who answered correctly on the definition of heat (no. 1) was 27 people $(96.4 \%$ ). This is different from result no.2. Students who answered correctly on no.2 were only $14.3 \%$. The questions tested on question no. 2 are the application of the concept of heat which should be if students can answer question no. 1 then they can answer no. 2 correctly. In question no. 2 it was found that many students thought that heat and temperature were the same. There is an inconsistency in the conceptions of students.

Effect of heat on changes in temperature and changes in form, the number of questions that discuss substances requiring heat to change form are no. 5. The number of students who said that substances require heat to change form is 22 people (78.6\%). The number of students who answered correctly on question no.9 (graphic illustration of the relationship between time and temperature of an object when a process of temperature change and shape change occurs) is 7 people. Many students think that as long as the process of transformation occurs, the temperature will continue to rise. This shows that students actually know that heat is needed in changing the shape of objects, but students do not know that during the process of change in form, heat does not cause changes in temperature.

\section{CONCLUSION}

Based on the results of research and discussion, it was concluded that the analysis of diagnostic data of three tier teststudents showed that of the five junior high school in lamongan district on the criteria of mastering the concept there $45 \%$, criteria undergoing misconceptions exist $35 \%$, guessing criteria or not being confident exists $10 \%$ while the criteria do not know the concept exists $10 \%$. This is due to the large number of alternative concepts and comes from students. 


\section{ACKNOWLEDGEMENTS}

The author would like to thank the Ministry of Research and Technology / National Agency for Research and Innovation for providing financial support for this research and to families who have always provided support and encouragement during the research process. To the entire academic community of the Islamic University of Darul 'Ulum Lamongan, who have provided support during the writing of this article.

\section{REFERENCES}

Aulia, S., Diana, N., \& Yuberti. (2018). Analisis Miskonsepsi Siswa Smp Pada Materi Fisika Analysis of Misconception of Junior High School. Indonesia Journal of Science and Mathematics Education, 1(2), 155-161.

Başer, M. (2006). Effect of conceptual change oriented instruction on remediation of students' misconceptions related to heat and temperature concepts. Journal of Maltese Education Research, 4(1), 64-79. https://doi.org/10.1061/(ASCE)07339410(1991)117

Berg, E. V. (1991). Miskonsepsi Fisika dan Remediasi. Universitas Satya Wacana.

Haryono, H. E. (2018). the Effectiveness of Science Student Worksheet With Cognitive Conflict Strategies To Reduce Misconception on Heat Concept. Jurnal Pena Sains, 5(2), 79. https://doi.org/10.21107/jps.v5i2.4510

Haryono, H. E. (2020). Jurnal Pendidikan Fisika Universitas Muhammadiyah Makassar The Implementation of Cognitive Conflict Learning Strategy in Efforts to Reduce Heat Misconception in Junior High School Students Implementasi Strategi Pembelajaran Konflik Kognitif Dalam. 8, 319-327. https://doi.org/10.26618/jpf.v8i3.3950

Haryono, H. E., Selirowangi, N. B., \& Aini, K. N. (2018). The Development of Worksheets IPA with Cognitive Conflict Strategy to Reduce Misconception in Heat Material. 3, 152-156.

Maison, M., Safitri, I. C., \& Wardana, R. W. (2020). Identification of Misconception of High School Students on Temperature and Calor Topic Using Four-Tier Diagnostic Instrument. Edusains, 11(2), 195-202. https://doi.org/10.15408/es.v11i2.11465

Matraeva, A. D., Rybakova, M. V, Vinichenko, M. V, \& Oseev, A. A. (2020). Development of Creativity of Students in Higher Educational Institutions: Assessment of Students and Experts. 8(1), 8-16. https://doi.org/10.13189/ujer.2020.080102

Paul, S. (2013). Miskonsepsi dan Perubahan Konsep dalam Pendidikan Fisika (Gramedia W).

Ramadhan, K. A., Suparman, Hairun, Y., \& Bani, A. (2020). The development of hotsbased student worksheets with discovery learning model. Universal Journal of 
Educational

Research,

$8(3)$,

888-894.

https://doi.org/10.13189/ujer.2020.080320

Şahoğlu, G., Yağc1, E., Konedrali, G., \& Yağc1, E. (2017). Assessment of Science Student Views on the Communicative Behaviours of Instructors. Eurasia Journal of Mathematics, Science and Technology Education, 14(3), 877-890. https://doi.org/10.12973/ejmste/80933

Sözbilir, M. (2003). A review of selected literature on students' misconceptions of heat and temperature. Boğaziçi University Journal of Education, 20(1), 25-41. http://buje.boun.edu.tr/en/images/stories/Vol20/20-1-3.pdf

Ulfah, S., \& Fitriyani, H. (2017). Certainty of Response Index (CRI): Miskonsepsi Siswa SMP pada Materi Pecahan. Seminar Nasional Pendidikan, Sains Dan Teknologi Fakultas Matematika Dan Ilmu Pengetahuan Alam Universitas Semarang, 341-349.

Wahidah S., S. N., Kusairi, S., \& Zulaikah, S. (2017). Diagnosis Miskonsepsi Siswa SMA di Kota Malang pada Konsep Suhu dan Kalor Menggunakan Three Tier Test. Jurnal Pendidikan Fisika Dan Teknologi, 2(3), 95. https://doi.org/10.29303/jpft.v2i3.295

Widiyatmoko, A., \& Shimizu, K. (2018). The development of two-tier multiple choice test to assess students' conceptual understanding about light and optical instruments. Jurnal Pendidikan IPA Indonesia, 7(4), 491-501. https://doi.org/10.15294/jpii.v7i4.16591 